\title{
In-Vitro Rument Liquid Characteristics (pH, VFA, and NH3) From Sugar Cane Top Fermented with Different Levels of Phanerochaete chrysosporium
}

\author{
Rani Winardi Wulan Sari ${ }^{2}$, Novirman Jamarun ${ }^{1}$, Elihasridas ${ }^{1}$, and Gusri Yanti ${ }^{2}$ \\ ${ }^{1}$ Lecturer of Animal Nutrition Department, Animal Science Faculty, Andalas University, \\ ${ }^{2}$ Postgraduate Student at Animal Nutrition Department, Animal Science Faculty, Andalas University \\ *e-mail: raniwinardi@gmail.com
}

\begin{abstract}
One of the limiting factors of utilization sugar cane top as animal feed was it's lower digestibility and feed consumption compared to grasses. Sugar cane top can be consumed by cows as much as less than $1 \%$ dry matter based on live weight. This due to high lignin content of sugar cane top and difficult to digested by ruminant animals. Therefore, sugar cane top should be fermented first before being given to livestock using Phanerochaete chrysosporium fungi at different levels. Therefore, fermentation using Phanerochaete Chrysosporium fungi is an effort to improve the quality of sugar cane top. The purpose of this study was to determine in-vitro rumen fluid characteristics $\left(\mathrm{pH}\right.$, VFA, and $\left.\mathrm{NH}_{3}\right)$ from fermented sugarcane tops with different levels of Phanerochaete chrysosporium. The method used in the experimental was randomized block design (RBD) with 4 treatments and 5 replications. The treatments were P0: Sugar cane top fermented with 0\% Phanerochaete chrysosporium, P1: Sugar cane top fermented with 5\% Phanerochaete chrysosporium, P2: Sugar cane top fermented with 10\% Phanerochaete chrysosporium and P3: Sugar cane top fermented with 15\% Phanerochaete chrysosporium. The parameter measured was in-vitro rumen fluid characteristics ( $\mathrm{pH}$, VFA, and $\mathrm{NH}_{3}$ ). The results of the experiment indicated that the parameters shown significantly different for each treatment of in-vitro rumen fluid characteristics $\left(\mathrm{pH}, \mathrm{VFA}\right.$, and $\left.\mathrm{NH}_{3}\right)$. The best result in this study was at $\mathrm{P} 1$ treatment (fermented with level of 5\% Phanerochaete chrysosporium) that is the $\mathrm{pH}$ : 6.43, the VFA: $116 \mathrm{Mm}$ and $\left.\mathrm{NH}_{3}: 5.78 \mathrm{M}\right)$.
\end{abstract}

\section{Keywords: Rumen fluid, $\mathrm{pH}, \mathrm{NH}_{3}, \mathrm{VFA}$, Phanerochaete chrysosporium}

\section{INTRODUCTION}

Ruminants are livestock that able to fulfill the needs of humans, which is a source of animal protein that has potential to produce milk and meat. Ruminant development in tropical countries generally places more emphasis on livestock systems that do not cause competition in land use and food needs. Therefore, ruminants play an important role because of their ability to convert feedstuffs that are not used by monogastric livestock, into meat and milk, as well as labor and transportation.

One of the determining factors in livestock business management is feed. Feed is one of the limiting factors in livestock development. Ruminant feed also comes from agricultural and plantation waste. In the current conditions, breeders have not used much of the existing agricultural and plantation waste as animal feed.

Sugar cane tops was is very potential plant waste as animal feed because it is available in large quantities and do not compete with human needs. Indonesia's sugarcane production in 2014 was recorded at 2,579,173 tons [1].

Sugar cane production from sugar cane plantations in South Sulawesi in 2012 amounted to 541 thousand tons. Sugar cane plants produce sugar cane top waste by $30 \%$. Sugar cane top contain $22.34 \%$ dry matter, $4.94 \%$ crude protein, $33.54 \%$ crude fiber, $1.34 \%$ fat [2], and $8.21 \%$ ash, and as well as $14 \%$ lignin [3].

Utilization of sugar cane waste in Indonesia is still limited to sugar cane top, and that is not yet widespread. One of the limitations of sugar cane waste from the sugar industry is its low digestibility and the level of consumption by livestock is not as much as grass. Sugar cane top can only be consumed by cows as much as less than $1 \%$ of live weight (in terms of dry matter). Therefore, sugar cane top need to be processed first before being given to livestock using Phanerochaete Chrysosporium at different levels. Therefore, fermentation using Phanerochaete Chrysosporium is an effort that can be applied to improve the quality of sugar cane top 
Phanerochaete chrysosporium is a mold from the class Basidiomycetes which has a strong ability to break down lignin effectively. The growth of Phanerochaete chrysosporium mold is influenced by the availability of minerals in the substrate, including minerals $\mathrm{Ca}$ and $\mathrm{Mn}$. Calcium is an inorganic element needed by almost all organisms, essential for the stability of protein structures [4] and cell membranes [5], also able to increase mold growth. The addition of 2400-3200 ppm Ca resulted in the best growth and activity of ligninolytic enzymes in $L$. squarrosulus and P.atroumbonata [6].

Phanerochaete chrysosporium has enzymes that function to degrade lignin (polysaccharides) into monosaccharides, water and carbon dioxide. Another advantage of these mold is that they can oxidize $\mathrm{Mn}^{2+}$ to $\mathrm{Mn}^{3+}$ which plays a role in breaking down the lignin phenolytic units. The CMC-ase enzyme contained in this mold can break down hydrogen bonds in the crystalline structure of cellulose into individual chains of cellulose. Phanerochaete chrysosporium can use cellulose which acts as a carbon source for its growth substrate and has the ability to degrade lignin.

The rumen condition was very important so that the digestion process of feed in the rumen can be optimal. This is because the digestion process of ruminants cannot be separated from the role of rumen microbes which are very helpful in the process of digestion and the provision of nutrients and energy for the ruminants. Microbes in the rumen play an important role in fermenting feed in the rumen, resulting in the production of VFA and $\mathrm{NH}_{3}$. The process of changing feed or fermentation of feed in the rumen is basically the work of enzymes produced by rumen microbes and is influenced by $\mathrm{pH}$ according to the needs of rumen microbes (range 6-7). In relation to this, it is necessary to study the percentage of use of sugar cane top as a mixture of alternative feed ingredients. So, to determine the use of sugarcane cane, it can be determined by measuring the characteristics of the rumen fluid $(\mathrm{pH}, \mathrm{VFA}$, $\mathrm{NH}_{3}$ ).

Biodelignification is a process of breaking down lignin to free fibers from its bonds using microorganisms such as mold, bacteria or enzymes [7]. From the above description, this study conducted to know the effect of different level of Phanerochaete chrysosporium" fermented to sugar cane Top as animal feed on In-vitro rument liquid characteristic ( $\mathrm{pH}, \mathrm{VFA}$, and $\left.\mathrm{NH}_{3}\right)$.

The materials used in this study were Panerochaete chrysosporium, mineral solution, rumen fluid, McDougalls solution, Potato Dextro Agar (PDA), aquadest, rice bran, $\mathrm{NaHCO}_{3}, \mathrm{Na}_{2} \mathrm{HPO}_{4} .7 \mathrm{H}_{2} \mathrm{O}, \mathrm{KCL}$, $\mathrm{MgSO}_{4} .7 \mathrm{H}_{2} \mathrm{O}, \mathrm{NaCl}, \mathrm{CaCl}_{2}$, and $\mathrm{CO}_{2}, \mathrm{Na}_{2} \mathrm{CO}_{3}, \mathrm{H}_{2} \mathrm{SO}_{4}$ $0.005 \mathrm{~N}, \mathrm{NaOH} 0.5 \mathrm{~N}, \mathrm{H}_{2} \mathrm{SO}_{4} 15 \%$, Phenopthalin, $\mathrm{HCl}$ $0,5 \mathrm{~N}$ for in-vitro used for fermentation and in-vitro nutrients digestibility measurements [8].

The equipment used in this study was a sickle tool, cutting tools, loop needles, erlenmeyer, incubator, sprita lamp, flow laminar, analytical scales, petri dishes, aluminum foil, measuring flasks, pipettes, and a set of tools for making McDougalls solutions, beaker glass, measuring flask capacity of 1 liter, $\mathrm{pH}$ meter.

The method used in this study was an experimental design, using a randomized block design (RBD) with 4 treatments and 5 replications. The treatments was P0: Sugar cane top fermented with $0 \%$ Phanerochaete chrysosporium, P1: Sugar cane top fermented with 5\% Phanerochaete chrysosporium, P2: Sugar cane top fermented with $10 \%$ Phanerochaete chrysosporium and P3: Sugar cane top fermented with $15 \%$ Phanerochaete chrysosporium.

\section{RESULT AND DISCUSSION}

Average values of acidity $(\mathrm{pH}), \mathrm{NH} 3$ and VFA of in-vitro rumen fluid from fermented sugar cane top with Phanerochaete chrysosporium can be seen in Table 1 .

\section{1. $\mathrm{pH}$}

The degree acidity of the rumen fluid $\mathrm{pH}$ is balance between buffer capacity and the acidity or alkalinity of the fermentation product. The $\mathrm{pH}$ value is influenced by the balance of VFA and $\mathrm{NH}_{3}$. Rumen $\mathrm{pH}$ influenced by a balancing between the VFA (acidic) value and $\mathrm{NH}_{3}$ (alkaline) value. [9]. The average $\mathrm{pH}$ value of the rumen fluid obtained in this study can be seen in Table 1 .

Rumen $\mathrm{pH}$ obtained in this study ranged from 6.43 to 6.96 that is normal conditions for the growth of rumen microbes. The results of this study did not indicate the optimal liquid $\mathrm{pH}$ for the development of microorganisms in these fluids. [10] The optimal rumen $\mathrm{pH}$ for the propagation of microorganisms is around 6.5-7.0.

The results of $\mathrm{pH}$ testing on treatment $\mathrm{P} 1$ and $\mathrm{P} 2$ were still in accordance with the $\mathrm{pH}$ conditions of the rumen fluid in the stomach cavity of ruminants. [11] $\mathrm{pH}$ conditions in the stomach cavity of ruminants range from 6.0-7.0. Meanwhile, [12] the activity of rumen fluid microorganisms ranged from 6.0-7.2. [13] $\mathrm{pH}$ of the rumen fluid drops to below 6 which can inhibit the proteolysis and deaminization process because the growth of cellulolitic microbes will be disturbed and the digestibility of crude fiber will decrease.

\section{2. $V F A$}

The average in-vitro rumen fluid FVA production can be seen in Table 1. VFA or Volatile fatty acids are carbohydrate fermentation products found in the rumen fluid. The carbohydrate content is the main energy source for ruminants.

Fermentation of sugar cane more affected by VFA production $(\mathrm{P}<0.05)$. VFA concentrations of rumen fluid in this study ranged from 104-116 mM. The VFA value in this study has met the optimum VFA level of rumen fluid. The optimum levels of VFA in rumen fluid range from 80$160 \mathrm{mM}[14]$.

High VFA production provides a sufficient source of energy for rumen microbes to reproduce more microbial cells are formed to produce enzymes. High VFA production is sufficient energy for livestock [15]. 
Table 1. The average in-vitro rumen fluid FVA production

\begin{tabular}{|c|c|c|c|c|c|}
\hline \multirow{2}{*}{ Characteristics } & \multicolumn{4}{|c|}{ Treatments } & \multirow[t]{2}{*}{ SE } \\
\hline & P0 & P1 & $\mathbf{P 2}$ & P3 & \\
\hline $\mathrm{pH}$ & 6.62 & 6.43 & 6.73 & 6.96 & 0.0678 \\
\hline VFA (mM) & 107 & 116 & 104 & 104 & 2.3541 \\
\hline NH3 (mg/100ml) & 7.48 & 5.78 & 7.89 & 8.99 & 0.3651 \\
\hline
\end{tabular}

Note :P0: Sugar cane top fermented with 0\% Phanerochaete chrysosporium,

P1: Sugar cane top fermented with 5\% Phanerochaete chrysosporium,

P2: Sugar cane top fermented with $10 \%$ Phanerochaete chrysosporium

P3: Sugar cane top fermented with 15\% Phanerochaete chrysosporium.

1. $\mathrm{NH}_{3}$

$\mathrm{NH}_{3}$ indicates the protein content in the rumen fluid. [17] $\mathrm{NH}_{3}$ comes from feed protein which is degraded by proteolytic enzymes in the rumen. $\mathrm{NH}_{3}$ is a major nitrogen source and an important microbial protein synthesis. The average $\mathrm{NH}_{3}$ concentration obtained in this research can be seen in Table 1.

The results of experiment showed that the treatment had a significantly different effect $(\mathrm{P}<0.05)$ between treatment of $\mathrm{P} 0, \mathrm{P} 1, \mathrm{P} 2$, and $\mathrm{P} 3$ on $\mathrm{NH}_{3}$. This indicates that $P$. chrysosporium will affect on value of $\mathrm{NH}_{3}$ content in rumen fluid. $\mathrm{NH}_{3}$ concentration in $\mathrm{P} 1$ was lower than the control. This is due to that $P$. chrysosporium mold requires more protein to develop its self. [18] Biodegradation process by molds requires energy and protein.

Along with the increase in the amount of $P$. chrysosporium mold added to the rumen fluid, the $\mathrm{NH}_{3}$ value increased. This is caused by an increase in the mass of the mold cells that contain protein. Extracellular enzyme secretion by $P$. chrysosporium also plays a role in increasing the biomass protein content of fermentation substrates.

The $\mathrm{NH}_{3}$ concentration value in the treatment has the minimum standard of $\mathrm{NH}_{3}$ content in rumen fluid, which is $3.74 \mathrm{Mm}$. [11] Minimum requirement for $\mathrm{NH}_{3}$ for the growth of rumen microorganisms is $5.0 \mathrm{mg} / 100 \mathrm{ml}$ of rumen fluid or the equivalent of $3.74 \mathrm{Mm}$. lack of nitrogen sources can reduce the production of rumen fluid microorganisms.

\section{CONCLUSION}

In-vitro rumen fluid characteristics $(\mathrm{pH}, \mathrm{VFA}$, and $\mathrm{NH}_{3}$ ) from sugar cane top fermented with different levels of Phanerochaete Chrysosporium showed significantly different on each treatments. The best result in this research was the P1 treatment (Sugar cane top fermented with level of 5\% Phanerochaete chrysosporium), that indicate the best vakue of $\mathrm{pH}, \mathrm{VFA}$ and $\mathrm{NH}_{3}$ that is $6.43,116 \mathrm{Mm}$, and 5.87 $\mathrm{Mm}$ respectively.

\section{REFERENCES}

[1] Kementrian Pertanian. "Outlook Tebu". Jakarta. Pusat Data dan Sistem Informasi Pertanian Sekretariat Jenderal - Kementerian Pertanian, 2016.

[2] Wardhani, N.K. and A. Musofie. Respon sapi perah dara terhadap pemberian wafer pucuk tebu dan rumput Gajah. Pros. Seminar Pemanfaatan Limbah Tebu untuk Pakan Ternak. Grati, 5 Maret 1985. Puslitbang Peternakan, Bogor. pp. 56 - 60, 1985.

[3] Alvino, H. "Pabrik Bioethanol Dari Ampas Tebu (Bagasse) dengan Proses Hidrolisis Enzimatis dan Co-Fermentasi". Laporan Penelitian. Institut Teknologi Sepuluh November. Surabaya. 2012.

[4] Martinez. A. T., M. Speranza, F.J. Ruiz Duenas, P. Ferreira, S. Camarero, and F. Guillen. "Biodegradations of lignocellulosics: microbial, chemical and enzymes aspects of the fungal attack of lignin”. Int Microbial, vol. 8, pp. 195-204, 2015.

[5] Jellison J. The Role of Cation in The Biodegradation by Phanerochatea chyrsosporium, APP. Environ Microbial, vol. 42, pp. 290-296, 1997.

[6] Wuyep, P. A., A.U. Khan, and A.J. Nok. "Production of Lignin Degrading Enzymes from Lentinus squarrosulus (Mont) Singer and Psathyrellaatroumbonata Pegler". African J Biotechnol, vol. 2, pp. 444-447. 2003.

[7] Singh, S. P and S.K. Roymoulik. "Role of Biotecnology in the Pulp and Paper Industry: A. Review. Part 1: Biopulping”. J. IPPTA, vol. 4, no. 4, pp. 53-56. 1993.

[8] Brook. E.J., W.R. Stanton and A.W. Bridge. "Fermentation Methods for Protein Enrichment of Cassava”. Biotech Bioeng. Vol. 11, pp. 12711284, 1969. 
[9] Arora, S. P. "Pencernaan Mikroba pada Ruminansia”. Gajah Mada University Press. Yogyakarta. 1989.

[10] Church, D. C. and W. G. Pond. "The Ruminant Animal Digestive Physiology and Nutrition". Prentice Hall, Englemood Cliff. New York. USA. 1988.

[11] Jamarun, N. dan M. Zain. "Dasar Nutrisi Ruminansia”. Jasa surya. Padang. 2013.

[12] Church, D. C. and W. G. Pond. "The Ruminant Animal Digestive Physiology and Nutrition". Prentice Hall, Englemood Cliff. New York. USA, 1988.

[13] Orskov, E. R. "Protein nutrition in ruminants". Academic Press Inc.(London) Ltd., 1982.

[14] Sutardi, T., N. A. Sigit and T. Toharmat. "Standarisasi Mutu Protein Bahan Makanan Ruminansia Berdasarkan Parameter Metabolismenya Oleh Mikroba Rumen”. Laporan Penelitian Direktorat Pembinaan dan Pengabdian pada Masyarakat. Direktorat Jendral Pendidikan
Tinggi. Departemen Pendidikan dan Kebudayaan. 1983.

[15] Sakinah, D. "Kajian Suplementasi Probiotik Bermineral terhadap VFA, $\mathrm{NH}_{3}$, dan Kecernaan Zat Makanan pada Domba". Skripsi. Bogor. Fakultas Peternakan. Institut Pertanian Bogor, 2005.

[16] Suparjo, "Saponin Peran dan Pengaruhnya Bagi Ternak dan Manusia". Fakultas Peternakan. Universitas Jambi: Jambi, 2008.

[17] Arora, S.P. "Pencernaan Mikrobia pada Ruminansia". Translated by R. Murwani and B Srigando. Gajah Mada University Press. Yogyakarta, 1995.

[18] Noferdiman, N., Rizal, Y., Mirzah, M., Heryandi, Y., \& Marlida, Y. "Penggunaan urea sebagai sumber nitrogen pada proses biodegradasi substrat lumpur sawit oleh jamur Phanerochaete chrysosporium". Jurnal Ilmiah Ilmu-ilmu Peternakan, vol. 11, no. 4, pp. 75-82, 2008. 